\title{
GSE Guarantees, Financial STABILITY, AND HOME EQUITY ACCUMULATION
}

\author{
Wayne Passmore and Alexander H. von Hafften
}

\section{OVERVIEW}

- Before 2008, investors in securities issued by Fannie Mae and Freddie Mac assumed that, in a crisis, the government would step in and honor the securities' payments. This implicit guarantee led to practices by Fannie and Freddie that threatened financial stability.

- Since the crisis, the nature of the government guarantee behind Fannie and Freddie has been an open question. Replacing the implicit guarantee with an explicit guarantee presents challenges. Many reform proposals instead focus on limiting the implicit guarantee by injecting private capital into the mortgage securitization process. The authors describe some limitations of this approach.

\section{- As a complement to this} approach, the authors recommend pursuing strategies that ex ante lower the likelihood and severity of crises. One strategy is the wider adoption of mortgages that build wealth faster than those favored by Fannie and Freddie and make homeowners less vulnerable to economic shocks. The authors highlight their work on the "Fixed-COFI" mortgage, which may be advantageous for many homeowners.
Tn September 2008, the newly created Federal Housing Finance Agency (FHFA) placed the Federal National Mortgage Association and the Federal Home Loan Mortgage Corporation into conservatorship (Federal Housing Finance Agency 2017). These institutions, known colloquially as Fannie Mae and Freddie Mac, are government-sponsored enterprises (GSEs) - institutions created by acts of Congress to fulfill a public mission but owned by private shareholders. Before 2008, the GSEs operated with minimal regulatory capital and had limited oversight. Conservatorship, originally intended to be a temporary fix, has now reached its tenth year.

This article examines the nature of the government's guarantee behind the GSEs. The U.S. government does not explicitly guarantee Fannie Mae and Freddie Mac. Instead, many private investors assume that there is an implicit guarantee-specifically, that the government will honor Fannie Mae's and Freddie Mac's promise of timely payment of principle and interest to purchasers of GSE mortgage-backed securities (MBS). These investors believe that, in an economic crisis, the fallout that would result from uncertainty about Fannie Mae's and Freddie Mac's readiness to keep this promise would be catastrophic. As a result, the government

\footnotetext{
Wayne Passmore is a senior adviser and Alexander H. von Hafften a financial analyst in the Division of Research and Statistics at the Board of Governors of the Federal Reserve System. Email:wayne.passmore@frb.gov; alex.vonhafften@frb.gov.

The views expressed in this article are those of the authors and do not necessarily reflect the position of the Federal Reserve Bank of New York, the Federal Open Market Committee or its principals, the Board of Governors of the Federal Reserve System, or any other person associated with the Federal Reserve System. To view the authors' disclosure statements, visit https://www.newyorkfed.org/research/epr/2018/epr_2018_gse-guarantees_passmore.
} 
would be compelled to honor the guarantee. Moreover, in the view of these investors, a GSE default would severely aggravate dire economic conditions.

How then should the government manage and price an implicit guarantee? We argue that legislating a definition of an explicit guarantee is difficult because the scope of the implicit guarantee is determined by the potential economic consequences of specific financial crises. Thus, the government should consider actions that ex ante limit the frequency and severity of housing-based financial crises, thereby making the need to act on the guarantee less likely. To limit such crises, the government could expand the types of mortgage contract structures supported by Fannie Mae, Freddie Mac, the Federal Housing Administration (FHA), and other government housing programs. Currently, the government promotes the thirty-year fixed-rate mortgage with the option to freely refinance and extract equity. The advantage of this mortgage is its level monthly payments, which may help households manage debt service. However, this mortgage can make the financial position of many households fragile because it accumulates home equity slowly; it also promotes consumption and leverage through refinancing. Minimal home equity holdings encourage strategic defaults and offer no cushion to help households ride out bad economic times.

We argue that the government could help households become more financially stable by promoting mortgages that encourage more home equity accumulation. An increase in the proportion of financially stable households may mitigate the social costs from severe financial crises and thus may reduce the pressure on the government to bail out MBS investors. Many mortgages already exist that encourage home equity accumulation, such as the Wealth Building Home Loan. ${ }^{1}$ In this article, we discuss the Fixed-COFI mortgage (Passmore and von Hafften 2018). ${ }^{2}$ The Fixed-COFI mortgage leads to rapid home equity accumulation and often allows households to pay off their homes relatively quickly.

In Section 1, we discuss what GSEs do and how their activities affect the stability of the financial system. We highlight the differences between explicit and implicit government guarantees in Section 2. In Section 3, we discuss the recent steps the GSEs have taken to inject more private capital into mortgage securitization and we examine the reliance of GSE reform proposals on these capital injections. In Section 4, we present a straightforward idea for encouraging household savings, thereby limiting implicit government guarantees. In Section 5, we consider a possibly more practical approach to GSE reform, in which the structure of the mortgage contracts themselves is modified. We present our conclusions in Section 6.

\section{GovernMENT-SPONSORED ENTERPRises and FinanCial Stability}

Fannie Mae’s current charter (Sec. 301) states:

The Congress declares that the purposes of this title are to establish secondary market facilities for residential mortgages, to provide that the operations thereof shall be financed by private capital to the maximum extent feasible, and to authorize such facilities to provide stability in the secondary market for residential mortgages; respond appropriately to the private capital market; provide ongoing assistance to the secondary market for residential mortgages (including activities relating 
to mortgages on housing for low- and moderate-income families); promote access to mortgage credit throughout the Nation; and manage and liquidate federally-owned mortgage portfolios in an orderly manner. ${ }^{3}$

The establishment of secondary market facilities for residential mortgages is among the many responsibilities this charter lays out for Fannie Mae. To establish these facilities, Fannie Mae and Freddie Mac (under its own similarly worded charter) provide a guarantee that the principle and interest of the MBS they issue will be paid in a timely manner. With the GSEs' guarantee, MBS investors know that the limited or nonexistent cash flows from a defaulted mortgage will not influence the payoffs from their investment. ${ }^{4}$ Thus, MBS investors do not bear the credit risk of the homeowners whose mortgages back the MBS they hold; instead, MBS investors bear the credit risk of Fannie Mae and Freddie Mac themselves.

Fannie Mae's charter also clearly states that Congress intended the GSEs to play an active role in maintaining the financial stability of housing markets, making as much use of private capital as possible. But do GSEs actually promote financial stability? In particular, do they promote financial stability in a manner that extensively utilizes private capital?

Before the financial crisis, three major factors were identified that suggested the GSEs actually endangered, rather than bolstered, financial stability (Gensler 2000; Greenspan 2005). First, the GSEs' implicit government backing lowered their funding costs, even though they held minimal regulatory capital. At that time, this implicit government subsidy contributed more than half of the GSEs' stock market value, but GSE primary mortgage rates were only 7 basis points lower than non-GSE primary mortgage rates (Passmore, Sherlund, and Burgess 2005; Passmore 2005). Thanks to the implicit guarantee, the GSEs dominated the mortgage market, yielding high profits but providing limited social benefits. Second, the GSEs-because of the size of their portfolios and their complex off-balance-sheet positions-had difficulty hedging against interest-rate shocks. As a result, their portfolios constituted a systemic risk. Moreover, exploiting the implicit guarantee enabled Fannie Mae and Freddie Mac to invest in capital-market instruments to increase their on-balance-sheet leverage, thereby growing their portfolios and profits. Third, market discipline over GSE management was lacking. The fear was that-even though private profits were substantial-management took risks that would eventually produce losses the public would have to cover.

The Housing and Economic Recovery Act of 2008 (HERA) included four pre-crisis prescriptions to address these financial stability concerns. Specifically, it: (1) increased GSE capital standards, (2) created the FHFA, a GSE regulator with expanded authority, (3) defined the resolution process for Fannie Mae and Freddie Mac, and (4) restricted the size of GSE investment portfolios, thereby limiting GSE debt issuance and leverage.

Shortly after HERA passed, the FHFA placed Fannie Mae and Freddie Mac into conservatorship, where they remain today. Under HERA, the FHFA's current options are continuing conservatorship, shifting the GSEs to receivership, or returning them to pre-conservatorship status. Other options for changing Fannie Mae's and Freddie Mac's status require legislation. Either receivership-which would involve dismantling the organizations-or a return to pre-conservatorship status would circumvent Congress's efforts to fundamentally reform the GSEs. For that reason, the FHFA has thus far opted to continue conservatorship. The FHFA's director stated, “. . I I am sensitive to the prospect that whatever steps FHFA could take might be misperceived as either an effort to promote recapitalization and release of the Enterprises or as interference with Congress's important work to advance housing finance reform" (Watt 2017). ${ }^{5}$ 
What HERA did not do was define a transparent and explicit government guarantee for Fannie Mae and Freddie Mac. Instead, the act temporarily authorized the U.S. Department of the Treasury to purchase GSE equity and debt. ${ }^{6}$ When the FHFA placed the GSEs in conservatorship, the Treasury purchased a large stake in their common stock. In subsequent agreements between the FHFA and the Treasury, the Treasury agreed to bear GSE losses in return for all GSE profits. These agreements—not explicitly spelled out in legislation-provide an effective government guarantee to GSE MBS holders during GSE conservatorship.

\section{Explicit AND Implicit GuARANTEes}

The nature of the government guarantee-whether explicit or implicit-remains at the heart of post-conservatorship GSE secondary mortgage market activities. Ultimately, GSE reform is about defining the role and substance of government guarantees in the secondary mortgage market.

The difference between an implicit and an explicit government guarantee is fundamental to this question. A guarantee is implicit when investors believe the government will intervene (even though it may say it will not) because failure to do so may lead to catastrophic economic or political consequences. Implicit guarantees reflect the complexities of managing and pricing catastrophic risk. With an implicit government guarantee, private sector market participants believe the "tail risk" associated with a catastrophe falls on the government (Davidson 2016).

Nonetheless, both before and after the FHFA placed the GSEs into conservatorship, GSE MBS prospectuses specifically stated that the government does not provide guarantees to MBS investors: "The certificates and payments of principal and interest on the certificates are not guaranteed by the United States, and do not constitute a debt or obligation of the United States or any of its agencies or instrumentalities other than Fannie Mae."7 Before 2008, market participants did not believe this statement, assuming correctly that the social costs threatened by GSE failure would compel a government bailout. Simply put, the government does not define implicit guarantees; the conviction of market participants that government crisis intervention is certain begets them.

In contrast, a guarantee is explicit when it is spelled out in legislation or regulations. Explicit guarantees define the circumstances that warrant government intervention. For example, Government National Mortgage Association (Ginnie Mae) securities prospectuses state: "The Ginnie Mae guaranty is backed by the full faith and credit of the United States of America." ${ }^{8}$ For the GSEs, an explicit guarantee would specify the conditions for financial assistance and the agency that would provide it if the GSEs were to get into financial trouble. An explicit guarantee may resolve uncertainty by encompassing an implicit guarantee. Alternatively, if market participants' views on government intervention encompass more than the explicit guarantee, an explicit guarantee may not actually resolve the problems associated with an implicit guarantee.

In principle, once it has made the conditions for intervention explicit, the government can manage and price such a guarantee. However, pricing an explicit guarantee may prove difficult in practice in a competitive secondary mortgage market. Hancock and Passmore (2016b) study the pricing of a government guarantee for losses associated with catastrophic risk in the mortgage market. Using data from the past decade's financial crisis, they find that a government 
insurer may be unable to price coverage in a manner that avoids government bailouts. If the government insurer prices to cover losses during a financial crisis, many secondary market participants may bypass government insurance in favor of private securitization. In contrast, if the government insurer prices competitively, that is, to match private insurance, the government insurance fund may be insufficient to cover all losses. To fully cover losses associated with a financial crisis using mortgage industry funding, the government must require participants to purchase expensive "through-the-financial-cycle" catastrophic risk insurance. Maintaining insurance fees at appropriate levels may prove politically difficult.

Private-sector insurers face similar dilemmas. Since financial crises are difficult to assess in an actuarially fair manner, pricing in a way that properly builds reserves against catastrophic losses is also difficult. As a result, the private sector may easily mismanage this catastrophic risk in the same fashion as the government. Infrequent systemic events of uncertain magnitude are difficult to price without either the belief or the promise of government intervention that will absorb the most extreme losses. As a result, a private market with "normal" pricing may require a credible government guarantee based on a tax or fee, similar to Federal Deposit Insurance Corporation (FDIC) deposit insurance.

Ultimately, private mortgage insurance distributes credit risk but cannot cover catastrophe or systemwide failure (Hancock and Passmore 2011). Only the federal government can back a guarantee in the face of systemwide failure. As a result, GSE guarantees overshadow those produced in private markets. In particular, GSE MBS trade in good and bad times, and they therefore carry a liquidity premium similar to Treasury securities. Investors might only stop trading them in bad times when the GSEs are at risk of becoming insolvent and government support is uncertain.

Apart from their use in calming economic turmoil, explicit guarantees can be utilized by the government to reallocate credit and redirect market activity to meet other objectives. The mortgages behind Ginnie Mae securities are mostly FHA and Veterans Affairs mortgages, and are oriented toward the social goals of providing credit primarily to first-time homebuyers and veterans, respectively. Explicit guarantees related to mortgage credit often reflect concerns about fairness and income redistribution. The government may be using explicit government guarantees either to manage catastrophic risk, which is probably an unavoidable cost for the government, or to change housing market outcomes, which is a policy choice.

Implicit government guarantees encourage market participants to trade GSE MBS, which can create much-needed liquidity during bad economic times. Conversely, implicit government guarantees can create liquidity problems if investors are concerned about GSE insolvency and doubt the GSE guarantee. GSEs can become insolvent in at least two ways. First, the process of securitization allows mortgage originators to retain higher credit quality mortgages on their own books and sell lower credit quality mortgages to the securitizer. This dynamic can cause the market to doubt the overall quality of GSE mortgage pools and the GSEs' ability to cover the losses during a crisis (Heuson, Passmore, and Sparks 2001). Second, GSEs, and the government generally, often misprice catastrophic risk insurance in the run-up to a crisis (Hancock and Passmore 2016b).

If GSEs are possibly insolvent in the midst of a severe financial crisis, then the government may need to intervene to prevent investors from losing confidence in GSE MBS. For example, in autumn 2008, doubts about GSE solvency and the credibility of government guarantees surfaced. GSE MBS liquidity only improved after the government placed the GSEs in conservatorship. In 
addition, GSE failure may accelerate a crisis because many financial institutions hold GSE MBS as safe investments, even though the GSEs hold little capital. Thus, an unexpected GSE default might have large destabilizing effects on many financial institutions. Finally, even a GSE guarantee may not be sufficient to maintain GSE MBS liquidity during severe market turmoil, as happened in autumn 2008 after conservatorship was established (Bernanke 2008). Although conservatorship helped GSE MBS liquidity initially, GSE MBS markets subsequently faltered again. Liquidity was only reestablished after the Federal Reserve began purchasing GSE MBS in November 2008.

The government could possibly resolve these problems if it explicitly defined the conditions for intervention during severe economic or financial downturns. Why then use implicit guarantees? First, the guarantee may remain implicit because of a political desire to keep the GSEs "off the books" of the federal government. An explicit guarantee might force the government to consider the GSEs in preparing its budget. Second, the question of who would regulate access and use of the explicit guarantee may be politically vexing. Before the financial crisis, Fannie Mae and Freddie Mac profited handsomely from the widespread belief that they had an implicit guarantee. That experience made many observers wary of the pre-crisis GSE structure. To increase profits, any institution with private shareholders and managers could be tempted to seek a government guarantee-whether explicit or implicit. Successful government management of an explicit guarantee, like FDIC insurance, may require an independent public institution to regulate use of the guarantee.

\section{Injecting Private Capital}

Fannie Mae and Freddie Mac had, and still have, private shareholders. Any losses from the GSEs' mortgage guarantees, beyond their loan loss reserves, fall on these shareholders first. (In a sense, Fannie Mae and Freddie Mac are like banks, whose unexpected credit losses hit private shareholders first.) However, prior to the crisis, the two institutions controlled the nature and scope of the implicit government guarantee. As a result, their management had strong incentives to minimize reliance on private capital, circumvent regulators, and increase leverage. Because of this pre-crisis experience with Fannie Mae and Freddie Mac, many GSE reform proposals have looked beyond the simple recapitalization of the institutions.

In this context, a dilemma vexes implicit guarantees: Efforts to make them more limited and explicit usually increase both the role of the private market and the cost of the guarantee. For example, some GSE reform proposals suggest that the government only bear the systemic catastrophic risk associated with the mortgage market, and the private sector bear non-catastrophic mortgage default risk and collect associated fee revenues. This insurance function seems well within the private sector's capacities, particularly during less-severe economic recessions and for limited periods of financial turmoil. However, an expanded role for the private market may increase overall mortgage costs.

Most current reform proposals envision injecting private capital into the government guarantee system through credit-risk transfers (CRTs). CRTs take many forms, including guarantees from private mortgage insurers, securities that transfer the credit risk associated with particular mortgage pools to private investors, and "mortgage putbacks"-agreements 
with mortgage originators about when defaults might result in the originator having to repurchase the mortgages (Zandi et al. 2017; Finkelstein, Strzodka, and Vickery 2018).

Regardless of the exact technique used, having more private capital behind GSE MBS may increase the cost of mortgage credit. To illustrate this point, we walk through the credit loss "waterfall," which orders investors based on who bears losses first and the amount of the loss they each bear.

The credit risk of a pool of mortgages can be divided into three tranches: expected losses, mezzanine losses, and catastrophic losses. Some mortgages are likely to default during the normal course of business. GSE loan loss reserves are established to cover these expected losses. Mezzanine losses are those losses that are beyond the expected level of defaults in the normal course of business but that can be estimated statistically. For banks, unallocated capital usually covers these losses. (For example, a bank might hold enough capital to cover 99.5 percent of simulated loss scenarios.) In recent years, Fannie Mae and Freddie Mac have successfully transferred the obligation to cover these losses to private investors using CRTs. The market prices of CRTs are similar to GSE guarantee fees. Mezzanine loss CRTs represent a promising way to employ private capital extensively. Indeed, many reform proposals (for example, Bright and DeMarco 2016, Mortgage Bankers Association 2017, and Parrott et al. 2016) utilize some form of CRT to bear the credit risk associated with the mezzanine loss tranche (Parrott 2017).

Nevertheless, some losses may ultimately fall on the holder of a mortgage's residual credit risk - that is, after the down payment, home equity, loan loss reserve, and mezzanine-loss CRTs are exhausted. These catastrophic losses are at the heart of the implicit guarantee. As previously noted, private markets find it difficult to establish a price for catastrophic losses. As a result, market participants perceive that catastrophic losses may sometimes force government intervention because the social costs associated with widespread mortgage defaults are so large.

To date, CRTs have not covered catastrophic losses. Indeed, effectively structuring such instruments might be difficult because some private purchasers may still expect government intervention, presuming that the government bails out debtholders when it believes the economic shock of all debtholders defaulting would be too extreme. For example, in the case of a severe recession or crisis, widespread holdings of mortgage credit risk through CRTs might actually make investors less likely to purchase or participate in programs to mitigate mortgage defaults. More generally, the government often finds that not absorbing catastrophic homeowner and institutional losses is politically difficult, given large and widespread negative social externalities; as a result, the government guarantee is often sold too cheaply ex ante relative to the costs of catastrophic risk, which generally makes pricing problematic (Hancock and Passmore 2016b).

If an institution with the full faith and credit of the government, such as Ginnie Mae, holds the residual mortgage credit risk, then investor uncertainty about MBS value under stressed conditions is mitigated. Alternatively, some proposals suggest that mutually owned, government-owned, or nonprofit corporations should act as the ultimate credit risk backstop. The regulation of this entity or entities, as well as the amount and quality of its capital, become important. Without these additional details, it would be difficult for investors to determine whether they should be concerned about the value of their MBS. If they do become concerned, the cost of mortgage credit may increase during business cycle downturns-the most inopportune time. In any GSE reform proposal, the capitalization and regulation of private GSE MBS guarantors are key questions because they frame the risk the federal government faces regarding bailouts of these guarantors and MBS investors. 
If private investors believe with absolute certainty that a combination of private capital and government funds will limit their losses during a systemic crisis, then they may be able to determine an actuarially based market price for mortgages. Alternatively, this price may be established if private investors believe that the social costs would be too large for the government to stand idly by during a catastrophe. However, if private investors are uncertain about government intervention in a crisis, then the cost of mortgage credit will likely increase because CRT investors may demand significant uncertainty premiums for bearing the credit risk.

Thus, implicitly guaranteeing private-market investors against long-horizon credit risks remains a dilemma: If implicit guarantees are credibly limited, mortgages become relatively more expensive during economic downturns. If implicit guarantees are not limited, instances of government risk taking, mortgage mispricing, moral hazard, adverse selection, and financial uncertainty and turmoil may increase. How then does the government credibly limit the implicit guarantees needed to maintain "normal" mortgage pricing without raising the cost of mortgage credit, particularly during volatile financial times?

One possibility is an FDIC-type insurance fund for mortgages (Hancock and Passmore 2011). Similar to deposit insurance, an FDIC-like guarantee for mortgages would be funded with insurance premiums. But, as noted earlier, increasing government liabilities or creating new institutions can be politically difficult. Moreover, given the desire for widely available, low-cost mortgage credit, the pricing of catastrophic insurance premiums could be challenging.

A different approach would be to lower the systemic risks in the mortgage and housing markets. One practical step may be to promote alternate mortgage structures that do more than the thirty-year fixed-rate mortgage to encourage homeowners to accumulate wealth and, in this way, better weather adverse economic events (Passmore and von Hafften 2018). ${ }^{9}$ Such mortgages exist, but homeowners and lenders currently have little motivation to explore them because of Fannie Mae and Freddie Mac's focus on the thirty-year fixed-rate product. Thus, the implicit GSE guarantee of a system of thirty-year, freely refinanceable fixed-rate mortgages, regardless of homeowner equity holdings, may have made financial instability and government bailouts more likely.

\section{Limiting Implicit Government Guarantees}

Keeping the social costs of a catastrophe in check may be the only way to limit an implicit government guarantee. For the GSEs, catastrophe would take the form of widespread mortgage defaults, which could be triggered by a substantial rise in unemployment or fall in house prices. One way to reduce the social costs of such a catastrophe would be to make homeownership a better method of wealth creation through the accumulation of home equity, which would in turn make households less vulnerable to shocks.

How can the government encourage homeowners to accumulate home equity? Our proposal is straightforward: The pricing and maturity of the government guarantee on a pool of mortgages could be related to homeowner home equity accumulation. ${ }^{10}$ Homeowners with mortgages that rapidly accumulate home equity could be charged a lower guarantee fee.

The nature of a recession would determine the usefulness of access to accumulated home equity. If unemployment were widespread but house prices remained stable, then more home 
equity might allow many unemployed homeowners to ride out the crisis. Similarly, if home prices fell substantially but employment remained stable, then more homeowners might be able to absorb the house price decline. They would have less incentive to strategically default-that is, to halt mortgage payments because the price of their homes had dropped, regardless of their ability to make those payments-and could ride out a temporary loss in their homes' market values until house prices bounced back. Fewer strategic defaults might reduce the need for government intervention in the housing market.

Our proposed pricing structure would encourage homeowners to choose mortgages that promote home equity accumulation. Greater home equity accumulation would to some degree limit the negative social externalities associated with a housing market meltdown, mitigating the pressure on the government to bail out homeowners. A higher GSE guarantee fee might partially internalize the negative social externalities associated with mortgages that do not promote equity accumulation.

Our suggestion about GSE guarantee pricing is independent of any institutional structure that may emerge from the GSE reform process. Regardless of the nature of GSE reform, the government has an interest in homeownership as a method of building wealth because wealth accumulation may limit the social costs of widespread mortgage defaults.

\section{Mortgage Design and Government Guarantees}

The traditional fixed-rate mortgage - the thirty-year, fixed-rate, fully amortizing loan without prepayment penalties_-dominates the U.S. single-family residential housing market. ${ }^{11}$ This mortgage seems simple: Homeowners pay a fixed amount each month over the life of the mortgage. However, it is far from simple behind the scenes. It is almost unique to the United States and rarely exists without substantial government backing. No natural private source of funding exists for such long-term debt; bank deposits and capital market instruments generally have much shorter maturities. Because households accumulate home equity very slowly-or not at all, given options to refinance and extract equity-the widespread use of traditional fixed-rate mortgages may aggravate systemic default problems during severe economic downturns.

A nominal thirty-year time horizon is too long for many private mortgage investors because severe recessions and depressions are probable over such a long period. ${ }^{12}$ As a result, a private secondary market usually requires long-term government credit risk guarantees in order to finance mortgages with thirty-year maturities. With government guarantees, securities backed by traditional fixed-rate mortgages maintain value, even when the economic outlook is poor. Otherwise, market participants would have to price catastrophic risk premiums into mortgage rates. ${ }^{13}$ During and after a financial crisis, these catastrophic risk premiums are likely to be large relative to the government's pricing. Indeed, private catastrophic risk premiums might impede economic growth (Passmore and Sherlund 2016, 2018).

We believe the government could encourage a wider variety of mortgages that both benefit homeowners and are more secure during financial meltdowns. We describe below a mortgage we have developed (Passmore and von Hafften 2018). Many other innovative mortgage designs could be helpful and should also be considered (for example, Oliner, Peter, and Pinto 2018). 
In Passmore and von Hafften (2018), we start by examining the traditional fixed-rate mortgage's shortcomings. First, homeowner equity accumulates at a glacial pace in the first ten years. Homeowners essentially rent their homes from lenders during the first decade of "ownership." To offset credit risk during this period, lenders require large down payments. ${ }^{14}$ Barriers such as high rent and student debt make large down payments unaffordable for many home buyers, even though the buyers may be creditworthy on a cash-flow basis. Second, capital-markets investors demand substantial compensation for bearing prepayment risks. Complicated risk management and hedging strategies are behind the scenes of these supposedly "simple" contracts. In essence, monthly mortgage payments include a lottery ticket. Winners lock in low interest rates for the remainder of the mortgage. Like any lottery, the odds favor the lottery operator. The homeowner pays premiums that are often greater than the expected value of the prepayment option. Even if homeowners "win" the lottery-that is, rates fall and they lock in at appreciably lower mortgage rates-they have often substantially compensated the mortgage holders and originators for their option to prepay. Third, repeated mortgage refinancing to take advantage of lower interest rates is often very expensive, typically costing several percent of the mortgage principal. And not all households benefit when interest rates fall because many miss optimal refinancing opportunities (Keys, Pope, and Pope 2016).

What is right with the thirty-year fixed-rate mortgage? Its level monthly payments, which allow households to manage their finances better. We propose a new product we call the Fixed-Payment Cost-of-Funds-Indexed mortgage (or Fixed-COFI mortgage), which also has a level monthly payment, equal to the payment of the traditional fixed-rate mortgage. ${ }^{15}$ At the same time, the Fixed-COFI mortgage resolves the three flaws of the traditional fixed-rate mortgage. First, large down payments or government backing are often not needed because Fixed-COFI mortgages encourage quick home equity accumulation. Second, capital-markets investors are not compensated for bearing prepayment risk; instead, monthly payments are directed toward purchasing the home. Third, homeowners with Fixed-COFI mortgages avoid deadweight costs associated with mortgage refinancing and always capture the advantages of falling interest rates.

The Fixed-COFI mortgage embeds an adjustable-rate mortgage based on the average cost-of-funds index (COFI) for the nationwide commercial banking system. COFI equals the total interest expenses of domestic commercial banks divided by their total interest-bearing liabilities. Hancock and Passmore (2016a) found that market participants would have received substantial benefits if they had used COFI adjustable-rate mortgages between 2000 and 2014. However, COFI adjustable-rate mortgages lack the desirable feature of constant monthly payments. By contrast, the Fixed-COFI mortgage has constant monthly payments.

As we show in Passmore and von Hafften (2018), the Fixed-COFI mortgage exploits the often-present prepayment-risk "wedge" between the traditional fixed-rate mortgage rate and the COFI mortgage rate. Estimated COFI mortgage rates are almost always below traditional fixed-rate mortgage rates, as shown in the chart on the next page. ${ }^{16}$ The wedge between the traditional fixed-rate mortgage rate and the COFI mortgage rate exists because the fixed-rate mortgage embeds large premiums for interest rate risk, prepayment risk, model risk, and uncertainty. A homeowner with a Fixed-COFI mortgage commits to a savings program based on the wedges between traditional fixed-rate mortgage payments and interest payments based on COFI plus a margin. The Fixed-COFI mortgage redirects these wedges toward purchasing the home. As a result, the Fixed-COFI mortgage leads to rapid home equity accumulation. 


\section{COFI Mortgage Rate Nearly Always Below Thirty-Year Fixed-Rate Mortgage Rate}

Effective thirty-year fixed-rate mortgage rate

- Estimated COFI mortgage rate

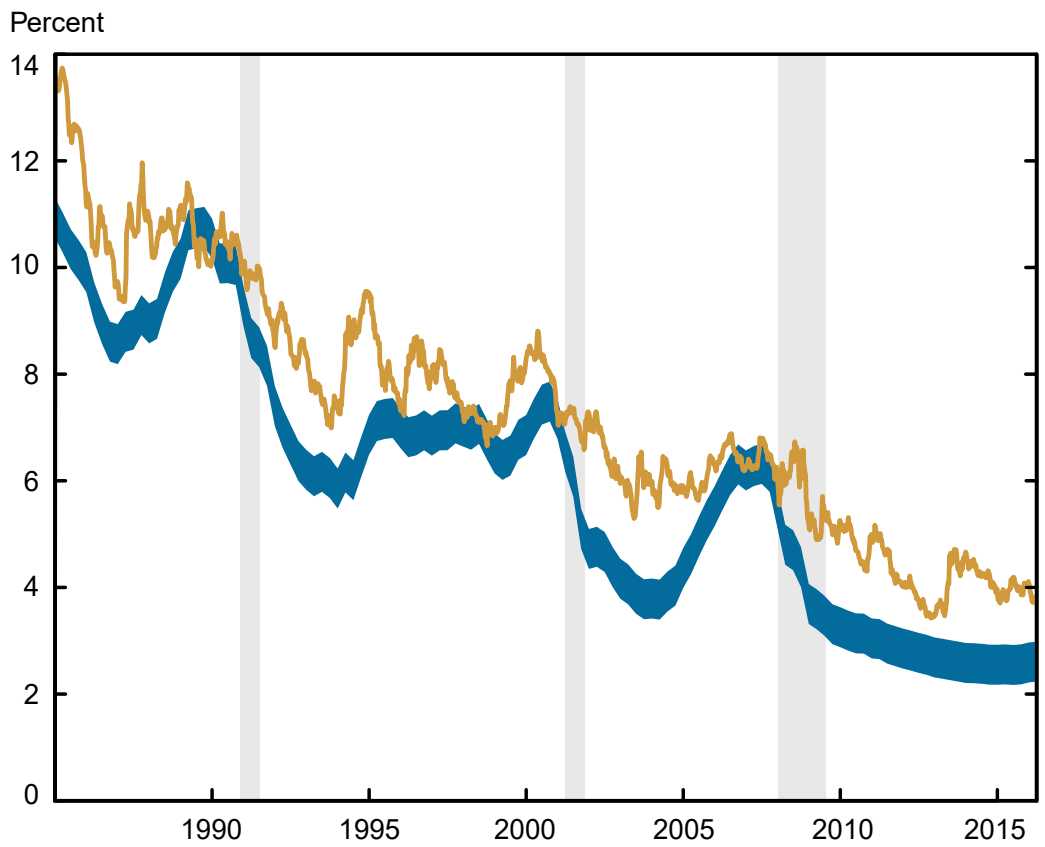

Sources: The Cost of Funds Index is constructed from the quarterly Federal Financial Institutions Examination
Council Call Report data, available at https://cdr.ffiec.gov/public/. Fixed-rate mortgage rates reflect weekly
Freddie Mac Primary Mortgage Market Survey data, available at http://www.freddiemac.com/pmms/pmms
archives.html. Estimated COFI-Cat mortgage gross margins are from Hancock and Passmore $2016 a$.
Notes: Estimated COFI mortgage rates are quarterly, with gross margins ranging from 1.75 to 2.5 percentage
points. The shaded areas indicate periods designated recessions by the National Bureau of Economic Research.

In Passmore and von Hafften (2018), we show that most Fixed-COFI mortgages pay off in far fewer than thirty years. We also show that these mortgages provide substantial interest savings to homeowners compared with traditional fixed-rate mortgages with similar down payments. The Fixed-COFI mortgage has a constant monthly payment equal to the payment of the prevailing fixed-rate mortgage at origination and requires little or no down payment. Homeowners with these mortgages always reap gains when interest rates drop. Banks can hold these mortgages for reasonable rates of return on equity. Moreover, as we also show, both interest rate risk and credit risk are much lower for Fixed-COFI mortgages than for traditional fixed-rate mortgages, and the cost of managing these risks is reasonable. The Fixed-COFI's secret is the wedge, which provides an extra cash flow because homeowners do not compensate capital markets investors for bearing prepayment risk. 


\section{CONCLUSION}

Private investors often assume that the social costs associated with systemwide mortgage downturns are so large that the government would be compelled to intervene. Thus, they assume that the government implicitly guarantees the GSEs and, therefore, their MBS. Consequently, widespread adoption of mortgage contracts that limit the social costs of housing market downturns might also limit the scope of the government's implicit GSE MBS guarantee. Better mortgage contract design may help stabilize our financial system. One such improvement would be the creation of mortgages that encourage homeowner wealth accumulation, something the freely refinanceable thirty-year fixed-rate mortgage does not always do. But mortgage contracts that promote wealth accumulation are feasible, and may benefit both homeowners and society in general. The government has an interest in promoting such contracts as a way of limiting the social costs of housing market downturns. And lowering those social costs would in turn keep in check the market's assumption of an implicit guarantee behind GSE MBS. 


\section{NOTES}

Acknowledgments: The authors thank Gillian Burgess, Chad Davis, Erin Hart, Shane Sherlund, Joseph Tracy, and James Vickery for their useful comments.

${ }^{1}$ Oliner, Peter, and Pinto (2018) details the Wealth Building Home Loan. In essence, it is a fifteen-year fully amortizing fixed-rate mortgage with a permanent rate buydown instead of a down payment. The interest rate buydown limits refinancing.

${ }^{2}$ In designing the Fixed-COFI mortgage, we aim to rethink mortgage design in general and the levers that can be pulled to customize mortgages in order to better fit the needs of individual households. In Passmore and von Hafften (2017), we introduce the Fixed-COFI mortgage contract and consider this mortgage with negative amortization, limited refinancing, and limited equity extractions. In Passmore and von Hafften (2018), we explore contracts with payment rebates and no negative amortization, and examine Fixed-COFI mortgage affordability across the United States. In both papers, we simulate Fixed-COFI mortgages over a wide variety of interest-rate environments.

${ }^{3}$ Federal National Mortgage Association Charter Act, 2010. Title III of National Housing Act, 12 U.S.C. 1716 et seq., http://www.fanniemae.com/resources/file/aboutus/pdf/fm-amended-charter.pdf. Freddie Mac's charter (http://www .freddiemac.com/governance/pdf/charter.pdf) uses similar language.

${ }^{4}$ In most cases, the GSE initially covers the payments from the defaulted mortgage. If the payments from the homeowner do not resume, the GSE removes the defaulted mortgage from the underlying mortgage pool and permanently substitutes its own payments for the missing cash flows.

${ }^{5}$ Melvin Watt became the director of the FHFA in January 2014.

${ }^{6}$ This authorization expired in December 2009.

${ }^{7}$ See Fannie Mae MBS prospectuses issued June 1, 2016, and March 1, 2002, at http://www.fanniemae.com/syndicated/ documents/mbs/mbspros/SF_June_1_2016.pdf and http://fanniemae.com/syndicated/documents/mbs/mbspros/ SF_March_1_2002.pdf.

${ }^{8}$ See Ginnie Mae prospectus issued 2010, Single-Family Mortgages, Pool No.: 719755XSF, at https://www.ginnienet.net/ sfprospectussearch.

${ }^{9}$ Eberly and Krishnamurthy (2014) present a mortgage with a different approach to helping homeowners weather adverse economic events. Their mortgage automatically converts from fixed-rate to adjustable-rate during a downturn. This conversion provides liquidity-constrained households with mortgage payment relief. Hancock and Passmore (2009) suggest several mortgages that enhance financial stability.

${ }^{10}$ Most private mortgage insurance already provides a similar incentive to homeowners who accumulate enough home equity to drive their loan-to-value ratios below 78 percent.

${ }^{11}$ Since the beginning of 2009, adjustable-rate mortgages have accounted for, on average, only 5.6 percent of weekly 


\section{NOTES (CONTINUED)}

mortgage applications. From 1990 to 2008, they accounted for 17.4 percent of applications, according to the Mortgage Bankers Association.

${ }^{12}$ Although the effective maturity of most traditional fixed-rate mortgages is much shorter than thirty years, refinancing and cash withdrawals allow homeowners to remain highly leveraged over long periods or even indefinitely. During the longer-term investment horizon of MBS investors, economic downturns may hit these highly leveraged households. To credibly cover this risk without a government backstop, substantial credit risk premiums might be needed.

${ }^{13}$ Losses from traditional fixed-rate mortgages are usually front-loaded, meaning they are likely to occur in the first ten years. However, with repeated refinancing and cash withdrawals, households can perpetually have a high risk of default.

${ }^{14}$ Alternatively, lenders require mortgage insurance, which increases mortgage payments. Private-sector insurance is costly and, as a result, the market relies on substantial government backing, particularly from the FHA.

${ }^{15}$ In Passmore and von Hafften (2018), we present two mortgage contract designs: the Affordable Fixed-COFI mortgage and the Homeownership Fixed-COFI mortgage. In this section, we focus on the Homeownership Fixed-COFI mortgage.

${ }^{16}$ Hancock and Passmore (2016a) estimate gross margins between 1.75 and 2.5 percentage points for COFI mortgages. The gross margin includes a profit margin, servicing costs, and credit risk guarantee fees. 


\section{REFERENCES}

Bernanke, B. S. 2008. “The Future of Mortgage Finance in the United States." Speech at the UC Berkeley/ UCLA Symposium: The Mortgage Meltdown, the Economy, and Public Policy, Berkeley, Calif., October 31. https://www.federalreserve.gov/newsevents/speech/bernanke20081031a.htm.

Bright, M., and E. DeMarco. 2016. “Toward a New Secondary Mortgage Market." ViewpoinTs. Milken Institute Center for Financial Markets. September. http://assets1b.milkeninstitute.org/assets/ publication/viewpoint/PDF/toward-a-new-secondary-mortgage-market.pdf.

Davidson, A. 2016. "Must Government Remain a Backstop for Fannie and Freddie?" Knowledge@Wharton. May 24. Video interview. http://knowledge.wharton.upenn.edu/ article/160523_the_future_of_fanniemae_and_freddiemac-andrew-davidson.

Eberly, J., and A. Krishnamurthy. 2014. "Efficient Credit Policies in a Housing Debt Crisis." Brookings Papers on Economic Activity (Fall): 73-136. https://www.brookings.edu/ wp-content/uploads/2016/07/fall2014BPEA_eberly_krishnamurthy.pdf.

Federal Housing Finance Agency. 2017. "History of Fannie Mae and Freddie Mac Conservatorships." https://www.fhfa.gov/conservatorship/pages/history-of-fannie-mae--freddie-conservatorships.aspx.

Finkelstein, D., A. Strzodka, and J. Vickery. 2018. "Credit Risk Transfer and De Facto GSE Reform." Federal Reserve Bank of New York Economic Policy Review 24, no. 3 (December): 88-116.

Gensler, G. 2000. Testimony before the Banking Subcommittee on Capital Markets, Securities, and Government-Sponsored Enterprises, U.S. House of Representatives, March 22. https://www.treasury .gov/press-center/press-releases/Pages/ls479.aspx.

Greenspan, A. 2005. "Regulatory Reform of the Government-Sponsored Enterprises." Testimony before the Committee on Banking, Housing, and Urban Affairs, U.S. Senate, April 6. https://www .federalreserve.gov/boarddocs/testimony/2005/20050406/default.htm.

Hancock, D., and W. Passmore. 2009. "Three Initiatives Enhancing the Mortgage Market and Promoting Financial Stability." The B.E. Journal of Economic Analysis and Policy 9, no. 3 (December). https://doi.org/10.2202/1935-1682.2226.

_ 2011. "Catastrophic Mortgage Insurance and the Reform of Fannie Mae and Freddie Mac." In M. Baily, ed., The Future of Housing Finance: Restructuring the U.S. Residential Mortgage Market. Washington, D.C.: Brookings Institution Press.

2016a. "Cost of Funds Indexed Mortgage Contracts with Government-Backed Catastrophic Insurance (COFI-Cats): A Realistic Alternative to the 30-Year Fixed-Rate Mortgage?" JournaL of Economics AND Business 84, issue C: 109-30. https://econpapers.repec.org/article/eeejebusi/ v_3a84_3ay_3a2016_3ai_3ac_3ap_3a109-130.htm. 


\section{REFERENCES (Continued)}

2016b. "Macroprudential Mortgage-Backed Securitization: Can It Work?” In S. Wachter and J. Tracy, eds., Principles of Housing Finance Reform. Philadelphia: University of Pennsylvania Press.

Heuson, A., W. Passmore, and R. Sparks. 2001. "Credit Scoring and Mortgage Securitization: Implications for Mortgage Rates and Credit Availability." Journal of Real Estate Finance and Economics 23, no. 3 (November): 337-63. https://link.springer.com/article/10.1023\%2FA\%3A1017952120081.

Keys, B. J., D. G. Pope, and J. C. Pope. 2016. "Failure to Refinance." Journal of Financial Economics 122, no. 3 (December): 482-99. https://www.sciencedirect.com/science/article/pii/ S0304405X16301507.

Mortgage Bankers Association. 2017. "GSE Reform Principles and Guardrails." January 31. https://www .mba.org/issues/residential-issues/gse-reform-principles-and-guardrails.

Oliner, S. D., T. Peter, E. J. Pinto. 2018. “The Wealth Building Home Loan.” Regional Science and URBAN ECONOMICs. In press. https://doi.org/10.1016/j.regsciurbeco.2018.07.012.

Parrott, J. 2017. "Clarifying the Choices in Housing Finance Reform." Urban Institute, Housing Finance Policy Center, March 13. https://www.urban.org/policy-centers/housing-finance-policy-center/ projects/housing-finance-reform-incubator/jim-parrott-clarifying-choices-housing-finance-reform.

Parrott, J., L. Ranieri, G. Sperling, M. Zandi, and B. Zigas. 2016. "A More Promising Road to GSE Reform." Urban Institute, March. https://www.urban.org/sites/default/files/publication/79771/2000746-a-morepromising-road-to-gse-reform.pdf.

Passmore, W. 2005. "The GSE Implicit Subsidy and the Value of Government Ambiguity." Real Estate Economics 33, no. 3 (September): 465-86. https://onlinelibrary.wiley.com/doi/ abs/10.1111/j.1540-6229.2005.00126.x.

Passmore, W., and S. M. Sherlund. 2018. "FHA and the GSEs as Countercyclical Tools in the Mortgage Markets." Federal Reserve Bank of New York Economic Policy Review 24, no. 3 (December): 28-40.

2016. "FHA, Fannie Mae, Freddie Mac, and the Great Recession." Finance and Economics Discussion Series 2016-031. Washington: Federal Reserve Board. https://doi.org/10.17016/ FEDS.2016.031r1.

Passmore, W., S. M. Sherlund, and G. Burgess. 2005. "The Effect of Housing Government-Sponsored Enterprises on Mortgage Rates.” Real Estate Economics 33, no. 3 (September): 427-63. https://onlinelibrary.wiley.com/doi/abs/10.1111/j.1540-6229.2005.00125.x 


\section{REFERENCES (Continued)}

Passmore, W., and A. H. von Hafften. 2017. "Improving the Fixed-Rate Mortgage." Finance and Economics Discussion Series 2017-090. Washington: Federal Reserve Board. https://doi.org/ 10.17016/FEDS.2017.090.

. 2018. "Financing Affordable and Sustainable Homeownership with Fixed-COFI Mortgages."

Regional Science and Urban Economics. In press. https://doi.org/10.1016/j

.regsciurbeco.2018.08.002.

Watt, M. 2017. Letter to the National Association of Realtors, August 9. https://www.aba.com/ advocacy/letterstocongress/documents/response-brown-nar-capital-reserves-080917.pdf\# _ga $=2.56708333 .690088807 .1507040264-1251184277.1507040264$.

Zandi, M., G. Harris, R. Shi, and X. Hu. 2017. "Who Bears the Risk in Risk Transfers?" Moody's Analytics, August. https://www.economy.com/mark-zandi/documents/2017-08-02-who-bears-the-risk.pdf.

The Economic Policy Review is published by the Research and Statistics Group of the Federal Reserve Bank of New York. The views expressed are those of the individual authors and do not necessarily reflect the position of the Federal Reserve Bank of New York or the Federal Reserve System. Economic Policy Review articles may be reproduced for educational or training purposes, provided they are reprinted in full; include credit to the author(s), the publication, and the Bank; and include the publication's disclaimer.

(C) 2018 The Federal Reserve Bank of New York 